\title{
LA SOBERANÍA SOBRE LA MUERTE: EL CASO VIOLETA PARRA ${ }^{1}$
}

\author{
REIGNING OVER DEATH: THE CASE OF VIOLETA PARRA
}

\section{MARÍA NiEVES ALONSO²}

\section{RESUMEN}

Muerte y poesía, como es siempre en literatura, aparecen profundamente aliados en la antología de la gran lírica chilena. Observamos continuidades y discontinuidades; estilos, subgéneros, modos de designación y apelación, revelaciones, ocultamientos, procedimientos antropomorfizantes, máscaras, ficciones, el poema convertido en cadáver, aceptación, androginia. En este contexto, el caso Violeta Parra, casi en la mitad de gran serie, es inquietante y consolador; exacto y múltiple. Este artículo estudia la dolorosa trayectoria del cuerpo de Violeta Parra y, como parte de éste, la obra, regida por la presencia de la muerte, cuya textualidad permite entender el último gesto físico y comprender que mantiene las cosas en su ser, y su función consiste en permanecer, pero también hacer "pasar", franquear los obstáculos, alborotar las cárceles y los secretos. Todo en esta obra, creo, cumple así las dos funciones míticas: unir y recuperar.

Palabras clave: Muerte, vida, canto, popular, Violeta Parra.

\section{ABSTRACT}

Death and poetry, as always in Literature, appear deeply linked in the anthology of great Chilean poets. We can observe continuities and discontinuities; styles, subgenres, forms of designation and appellation, revelations, disguising, anthropomorphizing procedures, masks, fictions, the poem converted in cadaver, acceptance, androgeny. In this context, in the case of Violeta Parra, almost in the middle of this great poetic series, it is unsettling and consoling; exact and multiple. This article studies the painful trajec-

${ }^{1}$ Artículo escrito dentro del marco del Proyecto Fondecyt No 1110921, "Poesía Chilena del Siglo XX: Esbozo de una historia de las relaciones entre poesía y muerte".

${ }^{2}$ Doctora en Filología Romance (Universidad Complutense de Madrid). Profesora del Departamento de Español, Facultad de Humanidades y Arte, Universidad de Concepción. Concepción, Chile. E-mail: malonso@udec.cl 
tory of Violeta Parra's body and, as a part of it, her work, ruled by the presence of death, whose textuality permits us to understand her last physical gesture and understand that she keeps things in her being and that her function is to prevail but also to "pass", overcome the obstacles that stir up her prisons and secrets. Everything in this work, I believe, fulfills two mythic functions: to unite and to recover.

Keywords: Death, life, popular song, Violeta Parra.

Recibido: 12.07.11. Aceptado: 21.09.11.

Este mundo es la puerta cerrada. Es una barrera y, al mismo tiempo, es también el paso.

Simone WeiL (1994, p. 13)

\section{AMOR, MUERTE Y CONDESCENDENCIA}

《

T OS HOMBRES querrían escapar de la muerte, extraña especie. $\mathrm{Y}$ algunos claman, morir, morir, porque quisieran escapar de la vida... Eso es lamentable y extraño, es un error”. Así escribe Maurice Blanchot en su íntimo y breve relato autobiográfico El instante de mi muerte (2004, p. 35). El notable filósofo ha descubierto, sin embargo, "seres que jamás le han dicho a la vida, cállate, y nunca a la muerte, vete". Esos bellos seres casi siempre, afirma Blanchot, han sido "mujeres [...] A los hombres, el terror los asedia, la noche los consume, ven sus proyectos aniquilados, su trabajo convertido en polvo. Ellos, tan importantes que querían construir el mundo, quedan estupefactos..." (Blanchot, 2004, p. 36). Pienso que una de esas bellas y complejas criaturas es Violeta Parra. En ella la relación vida-muerte es de tal espesura e intensidad que su escritura y existencia se convierten en una celebración de la vida y una apropiación de la muerte: encuentro radical: alianza y memoria que previene, requiere y crea una herencia irrevocable. La herencia artística y ética de la obra de Violeta no cesa hoy de interpelarnos; pareciera dirigir su llamado a nuestra propia mortalidad. ¿Cuál es el secreto, cuál el sacrificio, en la vida y obra de la autora de uno de los más tiernos registros epistolares, de una de las poéticas más entrañables, honestas y competentes ${ }^{3}$ que yo haya leído? ¿Qué relato se puede construir sobre la base de esta herencia irrevocable que se

\footnotetext{
${ }^{3}$ Hablo de competencia lingüística, semántica, gramatical; de esa capacidad del arte, de ciertos artistas para "sacarle el jugo al idioma" y ser testigos de su tiempo y de su pueblo a través de un lenguaje transparente y opaco; leve, espeso, múltiple, variable, rápido.
} 
hace más visible en las experiencias enigmáticas de la muerte de los otros? ¿Qué intercambios se establecen entre la poeta sobreviviente y los espectros de los difuntos?

Gracias a la vida... Y darse la muerte: vacío y plenitud; silencio y sonido; culpabilidad y responsabilidad; lanceta y herida; oscuridad y luz ¿Qué me invita a pensar e imaginar la dulce vecina del jardín florido sobre estos aparentes contrarios? Sobre sus bodas y su escándalo. Todo ello, por cierto, articulado dentro del flujo de la poesía chilena y las figuraciones, nombres y (des)aprecio de la muerte.

\section{YO NO CANTO POR CANTAR Y PARA ENVOLVER LOS BICHITOS YO ROMPO MI SILABARIO. PREPARADA PARA CANTAR, PREPARÁNDOSE PARA PARTIR}

La presencia de la muerte en la poesía y literatura de todos los confines y tiempos es una evidencia tan absoluta como la razón del origen de la tragedia. Es el círculo que Blanchot, lector de Kafka, llama "escribir para morir, morir para escribir, palabras que nos encierran en su exigencia circular, que nos obligan a partir de lo que queremos encontrar, a buscar sólo el punto de partida, a hacer así de ese punto algo a lo que sólo nos acercamos alejándonos, pero que también autorizan esta esperanza: allí donde se anuncia lo interminable, la de hacer surgir el término" (2004, p. 85). Así, la idea de la investigación en la que se inscribe este artículo es aquélla según la cual sólo se puede escribir si se permanece dueña(o) de sí ante la muerte, si con ella se han establecido relaciones de soberanía. El arte sería siempre relación con la muerte, porque esta es el extremo y quien dispone de ella, dispone en extremo de sí, está vinculado a todo lo que puede, es íntegramente poder y discurso. Se escribe, quizás, para no morir, para poner algo, como dice André Gide, al abrigo de la muerte, pero también se escribe para preparar ese único momento.

La obra, toda ella, y la vida de Violeta Parra, con sus continuidades y discontinuidades, géneros y subgéneros, modos de designación y apelación, rebeldía, revelaciones y ocultamientos, antropomorfismos, metonimias, sus contradicciones en acto, se constituyen en un caso del mayor interés en la historia de las relaciones profundas e inextricables entre poesía y muerte. Más aún, si ella es quien recoge, con intensidad, relevancia y conocimiento, la poesía popular que concede a su arte, entre otros aspectos, heterogeneidad, rapidez, levedad y visibilidad. Silencio entonces y que hable esta seño- 
ra, que repartía a manos llenas lo que recogía por los caminos y que sacaba fuego de los velorios (Neruda, 1982).

La lectura de los diversos registros poéticos, de cartas, de declaraciones y de testimonios de amigos y familia entregan los primeros datos para la aproximación a este asunto, ligado muchas veces al frío, la falta de luz, de cariño y de un lugar propio para este ser en quien la sed de cariño y amor es una constante indesmentible.

Llorar y reír, "las cuerdas de su guitarra decían melancolía, esperanza, rabia, gozo" (Parra, I., 2009, p. 29). Su canto, como los boleros, las rancheras, los corridos, los pasodobles, las tonadas argentinas, los tangos, las coplas españolas, los huaynitos que comienza cantando, van diciendo vida y muerte, amor y desamor, fiesta y funeral.

El canto popular, los velorios de campo, las cuecas en tarro, la música en la muerte, campanas tocando a muerto, las escenas de muerte en los bares de sus primeras actuaciones, le van anunciando "que todo tiene su término". El recorrido, según dice, de toda la geografía de la música fúnebre configura en su praxis un idiolecto en el que muy frecuentemente, en lo coloquial y poético aparecen lexemas, metonimias y giros ligados al vocabulario de la muerte: Disparo, disparar, tiro, cadáver, esqueleto, son palabras utilizadas más de una vez. Me permito citar algunos versos altamente reveladores de lo anterior: "mi corazón está de velorio / el humo de la vela quemada ya me llega hasta el cuello", "soñé que me moría de pena", "hasta cuándo los disparos de la inmunda cazadora sobre el alma de este pájaro", "así salía en la noche de luna o de oscuridad a recibir una vida, mientas otra se nos va", "como una píldora mal tragada, cogoteo mis tragedias personales", "tus piernas son ataúdes cadáveres", "sólo quiero un ataúd y un discurso ridículo", "día y noche disparan contra el ave indefensa", "agosto en París es cementerio", "Es mi manta, mi revólver que me ahuyenta el enemigo", "Estar separados es estar muertos... He estado muerta durante años", "Lo que creí casamiento se me volvió funeral".

Sus canciones-poemas incluyen situaciones del reino de la "Flaca" como llama a la muerte en sus décimas: Entre muchos, en "Casamiento de negros, amor", "Aquí tiene mi pañuelo", "Verso por el fin del mundo", "Verso por la niña muerta", "Se juntan dos palomitos", "Me voy por un senderito". Hay coplas que desangran la voz a cuchillo y está la apoteosis de morir por amor de "Cuando te vais a casar" o "Miren como corre el agua". Se nombra y figura la presencia de la muerte en toda su obra; sin embargo, es en sus Décimas. Autobiografía en verso donde es posible percibir la intensidad y las razones de Violeta y el límite. 


\section{TU DOLOR ES UN CÍRCULO INFINITO Y LA VERGÜENZA DEL SOBREVIVIENTE}

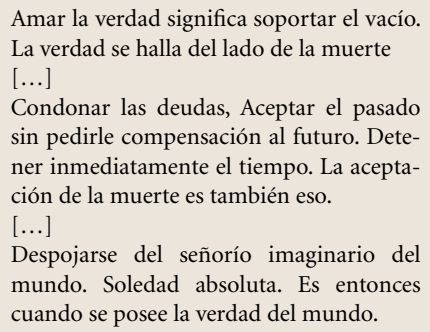

Despojarse del señorío imaginario del mundo. Soledad absoluta. Es entonces cuando se posee la verdad del mundo.

Simone WeiL (1994, p. 62)

Pablo Neruda, Pablo de Rokha, su hermano y maestro Nicanor poetizan la admiración por Violeta, al tiempo que dan testimonio de una fuerte personalidad artística y social intensamente conectada con la vida cotidiana y con la condición mortal del ser humano.

Así escriben:

De cantar a lo humano y lo divino, voluntariosa, hiciste tu silencio sin otra enfermedad que la tristeza

$[\ldots]$

Pero antes, antes, antes, Ay señora, que amor a manos llenas

Recogías por los caminos:

Sacabas cantos de las humaredas, Fuego de los velorios....

(Neruda en Parra V., 1998, pp. 9 y 10).

Tiene su arte aquella virtud de salud, que vital y mortal simultáneamente, de las honestas, recias y tremendas yerbas medicinales de Chile, que aroman las colinas o las montañas y las arañas con su olor a sudor del mundo del futuro, o lo remoto antiquísimo, y son látigos de miel dialéctica, con hierro adentro, en rebelión contra el yugo (De Rokha en Parra, I., 1998, p. 10).

Cuando se trata de bailar la cueca de tu guitarra no se libra nadie hasta los muertos salen a bailar cueca valseada $[\ldots]$ 
¡Nadie puede quedarse cuando tú cantas a media voz o cuando gritas como si te estuvieran degollando Violeta Volcánica!

¡Oh corderillo disfrazado de lobo! Violeta Parra!

(Parra, N. en Parra, V., 1998, pp. 15-16)

Sacristana cuyaca de Andacollo, lámpara a sangre, cocinera, niñera, lavandera: Viola funebris. También uno de sus grandes amigos, Gastón Soublette, me alerta sobre un rasgo muy notable del temperamento de esta mujer "rural como los pajaritos" que a veces atacaba como los relámpagos: "Entendí también entonces -escribe Soublette- que su creatividad, su coraje y la fuerza de su personalidad conllevaban una cara oculta donde se aposaba periódicamente una sustancia amarga e iracunda. Todos los seres tienen su parte de luz y su parte de oscuridad, dice Lao Tsé, y Violeta no hacía excepción a esta verdad fundamental: 'Era el precio que ella debía pagar por ser una persona excepcional, una mujer superdotada'” (en Parra, I., 2009, p. 55).

Leo los múltiples testimonios, leo su obra y pienso en un secreto, en la antigua noción de culpa cristiana y en ese nudo ciego del que habla con frecuencia la poeta. Pienso en el sentimiento de vergüenza, en el desasosiego del que tan hermosamente han escrito Pessoa y Tabucci; siento el dolor de la conciencia de la mortalidad y regreso al tema de nuestra investigación sobre las formas y figuras de la muerte en la poesía chilena.

Las Décimas de Violeta Parra, su autobiografía en verso, relata varios momentos en los cuales la muerte es parte fundamental del flujo vital poetizado. Hay en este sentido una situación, una experiencia iniciática para quien se asoma al mundo y que es una intensidad sorda de la que resulta difícil dar cuenta, asumir racionalmente o desterrar. Me refiero a la enfermedad, a aquella peste que la invade en el tren que lleva a toda la familia a Lautaro. Leo y transcribo:

Contra su pecho furiosa, como una joya preciosa, como una florida rama. Su tibia fald' en mi cama Era muy grande consuelo. La veo con sus desvelos, Humedeciendo mis labios, 
La fiebre me daba agravios, La sed me quita el resuello.

En este estado tan cruel Termina la diligencia Salimos de la presencia Fatal del maldito tren.

[...]

Viendo la preocupación que a mi maire dominaba, por las respuestas que daba supieron de su dolor le mandaron un doctor: después que nos instalaron al dueño nos encargaron con mucha solicitud si pienso en el ataúd que por miles le llevamos

Vinieron muchas visitas algunos a saludar algotros, a preguntar cómo estaba la guagüita detrás d'esa palabrita la flaca estaba acechando porque se van contagiando los pobladores s'espantan no saben qu'está pasando...

nadie sospecha jamás quién era la causadora de tales malditas horas; seguro no se sabía. Fue grande la mortandá Que ocasionó la inocente 4 .

(Parra, V., 1998, pp. 43-45)

\footnotetext{
${ }^{4}$ No registraré las formas y semántica del dolor o la pena también dominantes e intensísimas, pero naturalmente están conectadas y se funden en los requiebros de la muerte y su análisis. Violeta Parra, según piensa Simone Weil sobre este sentimiento "amar mucho la vida, para amar más la muerte... Porque amar la verdad significa soportar el vacío y, por consiguiente aceptar la muerte. La verdad se halla del lado de la muerte". Aún más "la agonía es la suprema noche oscura que incluso los perfectos necesitan para lograr la pureza absoluta, y para ello, es mejor amar... aceptar
} 
De este modo, a la niña que subió al tren, de cinta blanca en el pelo, abrigo de terciopelo, sandalitas de charol, el destino traidor le arrebata, sin piedad, su belleza y su candor y de lo que fue aquella flor no le quedó ni la sombra.

Hay en estas décimas tres conceptos que quisiera destacar: muerte, culpa, secreto y que, en mi lectura, al articularse con sus opuestos, generan una escena inicial en la cual planea un sentimiento que surge de una falta, marca, deuda o diferencia. Esto es la vergüenza.

Como se lee, la inocente Violeta es la portadora de una terrible lanceta, lo que la convierte en ayudante de los trabajos de "la flaca": "la flaca estaba acechando / porque se van contagiando / los pobladores s'espantan / no saben qu'está pasando...”. La familia guarda el secreto y la niña, aunque convertida en "orejón", "espanto", "garrapata", sobrevive.

No obstante, ha perdido el candor, ha vivido el encuentro terrible y los efectos de una cercanía y una culpabilidad difusa que la acompañará para siempre. Culpa negada por la inocencia y la alegría de la infancia y el secreto, pero que redunda en lo que Giorgio Agamben, en Lo que queda de Auschwitz (2005), llama "La vergüenza del sobreviviente". De este modo, y aunque la distancia y magnitud de los hechos que involucran a toda la humanidad, puedan parecer inconmensurables a nuestro caso, Agamben me da claves para entender el caso de Violeta Parra, el privado y entrañable caso de una artista que como pocos/as es testigo modalizador de su pueblo y compañía para quienes sabemos que lo que confiere al arte su poder de testimonio no son las palabras "sino la relación ambigua y desconcertante entre las palabras, la voz, el ritmo, la melodía, las imágenes, el silencio" (Agamben, 2005, p. 36) .

Lo señalado constituye en la obra y vida de la autora chilena una textura cuya clausura no ocurre en 1967, sino que expande sus saberes y dolores en lo que podría llamarse herencia o sobrevida de quien ve y busca a la Gorgona y consigue un arma liberadora frente a la pesadez de la situación extrema o del límite sin horizonte: Sobrevivir la ambigüedad insalvable que

el pasado sin pedirle compensación al futuro. Detener inmediatamente el tiempo. La aceptación de la muerte es también eso... 'Vaciarse del mundo'. Reducirse al punto que se ocupa en el espacio y en el tiempo. A nada. Despojarse del señorío imaginario del mundo. Soledad absoluta. Es entonces cuando se posee la verdad del mundo" (pp. 20,62 y 63).

${ }^{5}$ No me olvido de Adorno y su descarnada opinión sobre escribir, poetizar o hacer crítica después de Auschwitz: "La famosa plegaria de Rilke -en que se pide a Dios que dé a cada uno su muerte persona- no es más que un miserable engaño, con el que se trata de esconder que los hombres revientan y eso es todo... Toda la cultura posterior a Auschwitz, incluyendo la crítica de ella, es basura" (1987, pp. 284-331). 
supone una remisión a algo o a alguien a quien se sobrevive que puede ser uno mismo y a la propia vida en una existencia póstuma en la que el que sobrevive y aquello a lo que sobrevive coinciden. En este sentido, afirma Agamben, los autores cristianos (Violeta puede no serlo ${ }^{6}$, pero si su imaginería) pueden decir que Cristo -y con él todos los cristianos- en cuanto ha sobrevivido a la muerte es, a la vez, testador y heredero; el pecador, que estaría espiritualmente muerto, sobrevive a sí mismo en la tierra. Esto implica que la vida lleva con ella una cesura que puede hacer de cualquier vivir un sobrevivir y de cualquier sobrevivir un vivir. En un sentido -el que hemos encontrado en Belltelheim-, sobrevivir indica la pura y simple continuación de la nula vida; en otro, la supervivencia tiene un sentido positivo y se refiere -como en Des Pres-al que combatiendo contra la muerte ha sobrevivido a lo inhumano (Agambem, 2005, p. 140). Testigo integral, el testigo es ese resto ${ }^{7}$.

Pero volvamos a la vergüenza del sobreviviente, "esa irresoluble contradicción de la condición existencial del que ha sobrevivido". Éste, en tanto que ser de razón, sabe que no es culpable, pero su humanidad le impone, en el nivel emotivo, sentirse presa de la culpa: "Fue grande la mortandad que ocasionó la inocente". Saber, en el caso de Violeta que ocasionó que murieran seis escribientes, cuatro docenas de pacos y pa' pior se lleva el "saco el mal para San Clemente. Cayeron grandes y chicos, ricos y pobres...". El secreto -que tácitamente se decreta y en el que se vive el mal- acentúa la idea de falta y pecado, proyectándose así sobre la niña las primeras sensaciones, el fantasma, el pozo amargo de la vergüenza metamorfoseada en su cuerpo como pezuña y marca. Marca del elegido, marca del culpable, marca del sobreviviente inscrita en el mismo rostro, pero también huella y escritura de los difuntos que dominan la escena primigenia del encuentro de la poeta con la muerte: "la peste es un gran delito/ para quien tiene su huella" (p. 50). No obstante, la vida empuja y "con abundante inocencia",

${ }^{6}$ Será preciso estudiar la presencia del cristianismo, la imaginería, los personajes, cultura cristiana en la obra de Violeta Parra. De manera muy especial la culpa y la confesión.

${ }^{7}$ Giorgio Agamben estudia las circunstancias y caminos seguidos por Jorge Semprún y Primo Levi, ambos sobrevivientes. Uno, el sobreviviente total se transforma en "testigo ideal” y el otro, contradictoriamente, en lo que ya señalamos en "testigo integral” "absoluto": "El sentido y el no sentido de esta paradoja se hacen transparentes en este momento. Lo que expresa en ellos no es otra cosa que la íntima estructura dual del testimonio como acto de un 'actor', como diferencia y complementareidad de una imposibilidad y una posibilidad de decir, de un no-hombre y un hombre, de un viviente y de un hablante. El sujeto de testimonio está constitutivamente escindido, no tiene obra consistencia que la que le dan esa desconexión y esa separación y, sin embargo, no es reductible a ellas...” (Agamben, 2005, p. 158). 
poquito a poco la niña va armando sus jugarretas: "yo soy la feliz Violeta/ el viento me desaliña/". Viene pronto la salida al afuera, la agresiva relación con las compañeras, el colegio, pero asimismo hay complicidades, apoyo, amor y más juegos:

Malhaya! Los desesperos que paso con Marilú, rayaba mi canesú, diez veces me tira al suelo, me rompe libro y cuaderno. Por todo busca pelea, y luego me zamarrea cual pollo en corral ajeno (Parra, V., 1998, p. 59)

La pica es que la Violeta trinaba como canario repitiendo el silabario

(Ibidem, p. 59)

Cuando llegaba el verano con sus destellos dorados salíamos disparados a pulmonear aire sano (Ibidem, p. 65)

al río en tardes de sol como patitos al agua, felic’están chiquillos nadando como una tagua d`espaldas al arrebol...

(Ibidem, p. 67)

Llegan las dificultades económicas, la dictadura que practica el malvado, la maleza que va creciendo en la casa del profesor y de nuevo la muerte en la figura del hermano menor, Polito, el ángel al que velan 3 días y llevan al cementerio con alba color de armiño:

No tan ausente el criterio me anuncia muy pequeñita q' en libertad mi manita vive en cruel cautiverio...

(Ibidem, p. 78) 
Ya está corrido el telón, ya hay presagios en la mente de la niña. "Taitita, taitita de mis tormentos que está que lo lleva el viento con su flacura de muerte". En un día de gran quebranto y crecida pena, la partida del padre le hace pensar que "la muerte es un animal fatigoso y altanero, bullicioso y pendenciero", que cuando se llega a asomar "se siente un hielo que espanta, un miedo poroso que ningunito aguanta ni puede detener pues llega como un torbellino y sus dientes, como un molino, trituran al mortal. Satanás caníbal, la muerte es un tiburón, tragedioso y altanero" (Parra, V., 1998, p. 115).

Sin culpa, ni programa, el hambre caníbal del "tiburón tragedioso y altanero" todo lo invade; en el mismo velorio se arma un casorio del que nace otro ángel destinado al funeral como el propio cónyuge cuya vida amarga "aquella tonta murienta hasta que el pobre murió" (p. 120). Los versos por saludo, por procedimiento, por sabiduría y por despedida dedicados al pequeño expresan los sentimientos, los saberes múltiples -religiosos, populares, bíblicos- y una experiencia que la creadora va mezclando en su quehacer artístico que actúa aquí como voz de consuelo y expresión del ritual del pasaje y la despedida:

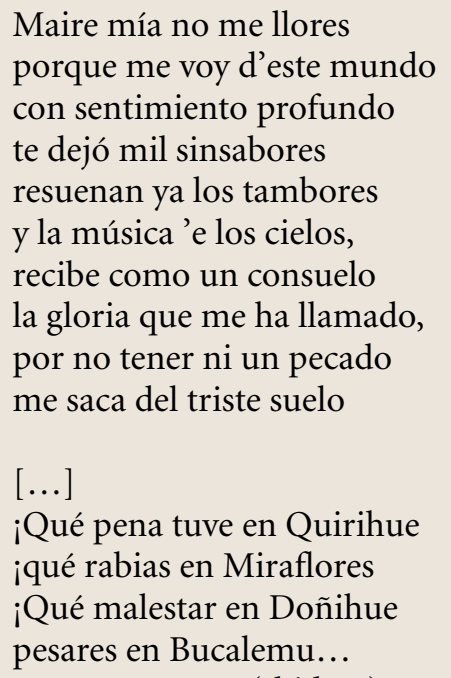

(Ibidem)

Angustias, tormentos, sobresaltos, hambrunas, delirios, desvelos, incertidumbre, suspiros, cansancios, flojera, nostalgia, aburrimiento, espantos, martirios, engaños, miedo, ataques, calamidad, pelambres, desdenes... toda la geografía para la pena y la desolación, sólo prosperidad en Niblinto, 
aplausos en Conchalí y en la Quebrá del Ají, amores y vino tinto hay para la "cantora infeliz".

La chilena errante, llamada así por su hermano Nicanor, deja su pueblo y viaja a la capital. El matrimonio con "un gandul de profesión ferroviario", el trabajo en cantinas y bares, la vivencia de otras pobrezas, le hacen añicos el corazón; el asesinato de la Tere, la sordidez de espacios-relaciones, le muestran la injusticia y la ineptitud de los códigos sociales al uso y la ley, aumentan el desacomodo y el desasosiego que trae prendido en el corazón. Como freno, protección y remedio está la poesía (la podesía) y el canto. Así fue antes, en Lautaro.

Sin embargo, todas estas muertes y durísimas vivencias son experiencias, $y$, aun la del padre, por prevista y esperada, que deben conectarse con otro acontecimiento perturbador. Me refiero a otra muerte, que intensificará y perfilará, creo que definitivamente, la relación de Violeta Parra con este extremo vital inexcusable, ya iniciada o fundada en la escena originaria que trasfigura a Violeta en sobreviviente tocada por los desasosegantes sentimientos de la vergüenza y la culpa.

Muy tarde, señor oyente, p'hablar de arrepentimiento; no mostré güen sentimiento estando el cuerpo presente, p' hablar de arrepentimiento [...]

Cuando regreso al país

El alto montón d'escombros

Que cae sobre los hombros

No encuentro ni la raíz

De un árbol que yo dejara

(Ibidem, pp. 183-184)

La muerte de Rosita Clara, durante la ausencia prolongada de Violeta, provoca un dolor tan profundo como la vergüenza, la culpa y el castigo que cree merecer quien reconoce haber olvidado pronto la pena de dejar a la pequeña inocente a la que no supo cubrir con su manto. Algunas décimas después, se lee:

Total con calma y salud voy enfrentando la vida, no debo estar afligida, lejos veo mi ataúd; 
algo tendré de virtud

como no ardo en maldiciones,

de nuevo con mis canciones

voy a juntar centavitos

y plantaré otro arbolito

que me dé sombra y amores.

Por último les aviso

Que Dios me quitó mi guagua

Y echó a funcionar la fragua

Que tiene en el paraíso,

Pasó por Valparaíso

En una linda corbeta

Que brilla como un cometa,

Me dice: en este vapor

Me llevé a tu hija menor,

Pero te tengo una nieta

(Ibidem, p. 184)

"Valor y condescendencia", "resignación infinita”, la idea del paraíso con mayúscula, pareciera ser que se asume la pérdida, la pena, con cristiano estoicismo y los auxilios habituales: amor y aire; trabajo y dedicación. Se abre así una posibilidad de porvenir y de disolución de la aflicción y la consiguiente indiferenciación entre vida y muerte. Dicha posibilidad se encuentra cifrada en el encuentro con la nieta. Ese encuentro con el otro pareciera constituirse en la fuerza disolvente por antonomasia de los poderes de la muerte. En el acontecimiento del encuentro con la nieta los efectos devastadores de los sentimientos de culpa y vergüenza se minimizan; son desplazados más bien por la infinita responsabilidad ante el regalo de vida cifrado en la nieta. ¿El poema y el canto no son acaso el lugar del acontecimiento de lo otro: espacio del llamado dirigido a la humanidad y mortalidad del otro?

La internalización artística de lo que antes se reconoce como despojo, "con calma y salud" y la responsabilidad ante otro ángel permiten seguir la vida. La sombra del castigo y el furor de la culpa se ausentan por momentos para, sin embargo, reaparecer intensificados en otros versos y en cartas:

Cuando yo salí de aquí

dejé mi guagua en la cuna, creí que la mamita Luna

me l' iba a cuidar a mí, pero como no fue así

pá a que el alma se me parta 
por no tenerla conmigo,

el mundo será testigo

que hei de pagar esta falta

[...]

Ahora no tengo consuelo,

y amargas como la sal

Vivo en pecado mortal,

(Ibidem, p. 188)

Punto y aparte, terminan las Décimas. Seguirán las penas de la Violeta volcánica, contradictoria y tierna. Veintiuno son los dolores, muchos los desengaños, van y vienen los pesares. Hay vida y muerte por delante y quien escribe "Gracias a la vida" se da / se otorga, años más tarde, muerte y activa una soberanía escandalosa para mi condición, no ya de pequeña burguesa, sino de cristiana que olvida que en el origen de nuestra salvación brilla una vida que sólo puede cumplir su travesía aceptando su propia muerte.

Efectivamente, el tercer momento de esta relación en vida es decidir el fin, el traspasar la frontera en una decisión soberana -originalmente el soberano es quien puede dar o quitar la vida- $y$, tal vez, en libertad.

Lo anterior lo podríamos sostener por el consuelo que significaría aceptar que la muerte "voluntaria o aceptada con pleno conocimiento de causa, es la manifestación suprema de la libertad, por lo menos de la libertad 'abstracta' del individuo aislado. Si creemos con fe absoluta que el hombre no podría ser libre sino fuera esencial y voluntariamente mortal" (Kojeve, 1983, p. 163).

Tal estilización de un acto que casi siempre es producto del más extremado dolor y ahogo, sería mistificadora y sólo podría atenuarse por la convicción de que sólo la certidumbre de la finitud y su anticipación convierte a un(a) artista en legataria. La sensación apremiante de la propia mortalidad, más aún, en el caso de Violeta Parra, su inmediatez y sentimientos consecuentes, constituye un aspecto que cruza toda la obra de la poeta, intensificándose con el tiempo que todo lo desbarata.

Ya hemos escrito sobre la conjunción de furia y ternura de esta chilena (huilliche-española) que parece aceptar el despojamiento como origen de su creación o que, como el español Antonio Gamoneda, sabe que la belleza tiene su origen en el dolor:

Violeta

Ya que conoces la treta

De la vers'a popular 


\section{Principiame a relatar \\ Tus penurias a "lo pueta"}

(Ibidem, p. 25)

Penurias, ternura y la búsqueda de la verdad hasta el límite (im)posible. Quien escribe "Gracias a la vida", quien es legataria de nuestro otro himno patrio, quien es tal vez la conciencia hospitalaria más intensa de nuestra poesía, quien es, junto a Mistral, nuestra madre y conciencia de la patria es una suicida. Pero que en su vida se juega contra el olvido y la desmemoria y en su obra -y en su muerte como en la de Lorca o Levi- se juega y se accede a su sobrevida y su permanencia.

Viva hasta (en) la muerte, Violeta logra hacer el cruce, la boda entre el tiempo de la escritura, el tiempo mortal de una vida singular, y el tiempo de la obra que es el de la "perdurabilidad ignorante de la muerte". De este modo, como escribe Paul Ricoeur, la cuestión es ante todo una cuestión de sobrevivientes. Es que nos preguntamos si también los muertos siguen existiendo, sobre el coraje de afrontar la muerte a través de la escritura, sobre la tentación del suicidio ¿La poeta se mató, como Primo Levi, porque quizás su plegaria no fue escuchada, porque no pudo dar simbólica sepultura a los espectros que la acompañaban desde la escena primordial?

Que difícil y qué arduo -había dicho Spinoza- es el camino que C. E. Magny señalaba al futuro escritor: "Nadie puede escribir si no tiene el corazón puro, es decir sino está lo bastante desprendido de sí [...] La escritura, si pretende ser más que un juego, o una apuesta, no es sino un largo camino de ascesis, una manera de desprenderse de sí comprometiéndose: convirtiéndose en sí mismo por haber reconocido, traído al mundo al otro que siempre es uno" (Subirats, 1983, pp. 303-304).

Tal es el nudo: trabajo de memoria es trabajo del duelo... Sí, alcanzar el punto donde la "verdad" que expulsa los espectros es ésta: "la eterna lucha entre la fraternidad y el mal absoluto" (Ricoeur, 2008, pp. 60-61). Es decir, vencer el mal absoluto que es la obsesión nacida de la experiencia de la muerte, de la presencia de la muerte en situaciones límites y no hay anamnesis sin "exorcismo", sólo hay duelo inconcluso: "Sólo un suicidio podría signar, poner fin de manera voluntaria a ese trabajo de 'duelo inconcluso'. Tal vez era preciso" (Ricoeur, 2008, p. 57). Nadie puede escribir su propia muerte, tampoco se puede pretender hacer ese relato. Violeta vive una anticipación, una agonía desde muy temprano y va ficcionalizando su estar en el límite, dando claves que hablan de esto y otorgan el sentido de liberación al momento en que una pistola se convierte en parte o extensión de su propio cuerpo y parece poner en orden una serie de hechos que posibilitan 
y producen aquello que no ocurre, porque las cosas son agenciadas por el propio sujeto en ausencia de testigos. Muerte en soledad, imposibilidad en vida de deshacer el nudo ciego que constantemente ahoga y que parece cortarse con la muerte, la forma última de llorar, pero también la forma última de rogar, de pedir perdón, por sí misma, por los difuntos que habitan su palabra, por los seres que su alma acogió con hospitalidad y responsabilidad:

No lloro yo por llorar sino por hallar sosiego mi llorar es como un ruego que nadie quiere escuchar...

... ya está corrido el telón:

la fiesta sigue su curso mi largo y triste discurso es parte de la función...

(Ibidem)

Tres momentos, dije, destacan en este relato: la gran epidemia, la ausencia y la muerte a sí debida. En las epidemias, escribe Paul Ricoeur, el sobreviviente provisorio -todos seríamos eso- está rodeado, circunscrito por la masa indistinta de moribundos, y habitado por el sentimiento de la muy grande probabilidad de su muerte próxima, de la inminencia de esa muerte. Entonces se imagina, se percibe como si ya formara parte de esa "masa indistinta de los muertos y de los moribundos". La "obsesión" pone al sobreviviente frente a dos alternativas: o vivir a costa de olvidar, escribir, contar, pero verse impedido de vivir, porque la muerte superada sería el verdadero real y la vida un sueño, una ilusión. Pero, se pregunta el filósofo francés, ¿̇hasta qué punto no es ella misma una obsesión a destiempo? Sobrevivir es, entonces, haber sido dispensado de ello, los dispensados de la peste tendrían para siempre la marca y la deuda de la liberación. Es posible, más bien sin duda, la niña Violeta no racionaliza de este modo su experiencia con el contagio, pero esta experiencia establece la fiebre que atraganta y dispone en su discurso los significantes de la muerte.

El segundo momento del relato es la culpa por ausencia y la muerte de la hija: quien naturalmente debería sobrevivir a la madre. Inversión de la situación anterior, aquí es la inocente la que es llevada y la madre viva la abandonadora, pero para siempre con el alma partida y marcada por la vergüenza y la culpa. Sólo el encuentro con la nieta exorciza los demonios de la vergüenza y la culpa a la vez que transfigura a Violeta en un ser infini- 
tamente responsable ante el otro. De este modo, es posible comprender la incansable búsqueda de la verdad y la justicia que caracteriza la vida y obra de la poeta, pues, lo sabemos con Levinas, la relación con el otro se dirige a la consecución de ambas.

Cuerpo y alma marcadas y a la búsqueda del amor -en sus variadas vertientes- y la obra como ejercicio de salud y constitución de una unidad que batalle contra el gran mal, que se opone a la fraternidad: ¿no es preciso entonces que el mal sea nombrado para que la muerte sea y, nombrada, avance activa contra nosotros... al mismo tiempo se perfila un camino difícil: "Si el duelo debe pasar por el exorcismo de los espectros generados por ese mal a partir de la 'massa perdita' donde moribundos y cadáveres se confunden" (Ricoeur, 2008, pp. 47-51).

Con esos espectros se bate Violeta Parra, ellos dan origen a la alternativa de vivir o escribir y no poder ya vivir... Para conjurar y exorcizar el horror hay que pasar pues por el trabajo de la memoria y el trabajo de duelo y, entonces, recién tal vez ser libre y elegir o pensar en el amor.

Escritura, creo, de apropiación y conjuro del ayer individual y colectivo en la que todo poema deviene elegía, réquiem o denuncia. Recreación de la intensidad que se encuentra a salvo sólo en la memoria y la escritura. Esta poesía del recuerdo y de las penas de amor es, sin embargo, irreductible a la pura significación pretérita dentro de la cual puede ser encerrada. Su obra sigue fabulando provocadoras conexiones de la individualidad y sus penurias con su sociedad y la política. Violeta escribe con sus recuerdos de lo perdido, pero no por narcisismo, sino porque ellos le permiten conectar lo individual con los males sociales y los fuegos de artificio de la política.

No tiene fuego la Luisa, ni lámpara, ni pañal.

El niño nació en las manos de la que cantando está:

Por un reguero de sangre mañana irá el Cadillac

¡y viva la libertad!

La fecha más resaltante, la bandera nacional

La Luisa no tiene casa. La parada militar...

("Yo canto a la diferencia")

Y el amor que abandona, el amor que vuelve a dejar 1.000 grados bajo cero la carpa, las otras razones. Lo que sí puedo afirmar es que su muerte es un momento en la magnífica tarea de Violeta para darnos, sin anunciarlo, una hospitalidad, un lugar en la lengua, una fraternidad que, tal vez, algo, aunque insuficiente, hemos sabido reconocer. 
Su triunfo: la obra, su "Gracias a la vida", sus hijos, nietos, bisnietos, sus lectores, admiradores, discípulos. Su saber entregarse a la tierra para volar por los cielos y volver del otro lado de la noche. Esto porque su trabajo, sus poemas, arpilleras, toda su creación, operan como talismanes, como seguro, sobrevida, encuentro.

\section{IV. “AQUÍ TIENE MI PAÑUELO, SEÑORA, SEQUE SU LLANTO. LA VIDA-LA OBRA}

Un día veremos la resurrección de las mariposas di-
secadas y aun andando por un paisaje de esponjas
grises y barcos mudos veremos brillar nuestro anillo
y manar rosas de nuestra lengua.

Federico García Lorca

Violeta Parra muere el 5 de febrero de 1967 en su carpa de La Reina. Consuelo, alivio, deuda, insuficiencia, a partir de esa fecha y hasta hoy aparecen y se realizan grabaciones, homenajes, notas de prensa (en 1991, Inés Dölz recoge más de 500). El constante y fervoroso trabajo de sus hijos Isabel y Angel y la creación de la Fundación que lleva su nombre, son imprescindibles y presencias indispensables en el cuidado del legado de la artista. Se registran libros que incluyen aproximaciones biográficas: Bernardo Subercaseaux y Jaime Londoño (1976), Patricio Manns (1986), Isabel Parra (1985, 2009, incluyen poemas, canciones, cartas, testimonios), Carmen Oviedo (1990); Una biografía novelesca: Mónica Echeverría (2010); ediciones y antologías: Décimas. Autobiografía en versos chilenos (1970), Cantos folklóricos chilenos (1979).

La atención académica no es particularmente abundante. En 1997, Susana Mulnich concluye que este hecho se debe a la preocupante dependencia cultural que se vive en Chile. Naomí Lindstrom le dedica un artículo en el que habla del valor y sentido de su voz "chillona". También se publica el libro de Marjorie Agosin e Inés Dölz-Blackburn: Violeta Parra: Santa de pura greda (1988) y, en diciembre de 2000, encuentro un documentado y hermoso texto de Selena Millares ${ }^{8}$. Poco, pues, para una voz que parece inextinguible.

¡Ay qué manera de caer hacia arriba y de ser sempiterna, esta mujer!, la que fue y sigue siendo, expresaron Pablo Neruda y Nicanor Parra. Hasta los

\footnotetext{
${ }^{8}$ Selena Millares (2000) presenta y resume la bibliografía sobre Violeta Parra en su artículo “Geografías del Edén: La poesía trovadoresca de Violeta Parra”. Allí mismo desarrolla un hermo-
} 
muertos salen a bailar con ella la que llegó al mundo con tres dones el del amor, el del arte, el de la vida. Amor y arte, ya lo dije, las dos defensas ante la gran herida.

Así la vida de la "Violeta funebris", como el musguito en la piedra, va enredando, enredando, su gran necesidad de dar y recibir amor con una creación entendida como recuperación, deber, trabajo y ejercicio de hospitalidad para el pueblo que falta y del que ella es parte y que siente es necesario crear o recuperar. Pueblo que falta cuya presencia más escandalosa la constituyen los espectros del ayer.

Válgame Dios, Nicanor,

Si tengo tanto trabajo

Que ando de arriba p'abajo

Desenterrando folklor

No sabís canto dolor,

Miseria y padecimiento

Me dan los versos que encuentro

Muy pobre está mi bolsillo

$\mathrm{Y}$ tengo cuatro chiquillos

A quienes darle el sustento.

En ratitos que me quedan

Entre campo y grabación

Agarro mi guitarrón,

O bien mi cogot 'e yegua

Con ellos me siento en tregua

$\mathrm{Pa}$ ' reposarme los nervios

[...]

Tomé la pluma en la mano

Y fui llenando el papel

Luego vine a comprender

Que la escritura da calma

A los tormentos del alma

Y en la mía que hay sobrantes...

(Ibidem, p. 27)

so contrapunto jardín/contrajardín y concluye así: "Voz telúrica y celeste Violeta Parra parece condensar en su propio nombre la paradoja de su poderoso don para la creación: el rojo y el azul ese color sugestivo que habla de flores sombrías asimiladas al fatalismo de la muerte -Neruda hace esa lectura de su apellido, 'Parra eres y en vino triste te convertirás' (Neruda, 1982, p. 32); pero igualmente las violetas -flor integrante de su jardín imaginario- son el antídoto para los pesares, como nos lo cuenta la propia cantora -'para mi tristeza' (Nicanor Parra, 1983, p. 16)-, quien igualmente la vincula con un destino fatal: 'Viola funebris' (Ibíd, p. 165). Jardín del canto y de la poesía, la trascendencia de su legado nace no solo de su hondo lirismo sino también de su universalidad: la savia matricial de toda una colectividad renace en cada uno de sus versos, y su permanencia habla por sí sola”. 
Igualmente las canciones permiten soportar la fealdad que la rodea en historias al por mayor:

$$
\begin{aligned}
& \text { Llegaron como colmenas } \\
& \text { hombres de caras morenas } \\
& \text { al pérfido restauran } \\
& \text { se ponen a conversar } \\
& \text { como podrido estropajo } \\
& \text { de la cintura p'abajo } \\
& \text { Los cubro yo mi canción }
\end{aligned}
$$

(Ibidem, p. 156)

Las precisiones anteriores y otras como: "Al ritmo de una canción/ voy ordenando la pieza; /me cruzan por la cabeza/ como palomas los sueños. Mi voluntad jura empeño/ de arrear con esta pobreza"; "a los diez años/ cumplidos/ por fin se corta la güincha,/ diez vueltas daba cincha/ al pobre esqueleto mío,/ y p'a saborear el senti'o/ volví a tomar la guitarra/con fuerza Violeta Parra/ y al hombro con dos chiquillos/ se fue para maitencillo..." (Parra, V., 1998, p. 148.) hacen innecesaria cualquier glosa o reiteración de lo ya dicho por la artista.

Violeta canta a la diferencia que hay de lo cierto a lo falso y si levanta su grito es para producir un efecto que, para ella, es el de la verdad, esa utopía o necesidad que persigue para vivir en la generosidad, en la responsabilidad ante el otro, en la sonoridad que ha vivido varias veces con amigos y familia y en el amor al que porfiadamente vuelve, aunque éste queme el árbol del mismo amor y sólo deje cenizas al pasar. Jardines humanos, amor y condescendencia, sabe que hay que cantarle "al hombre en su dolor, en su miseria y su sudor, en su motivo de existir". El canto, su obra, es para ella un azadón que le abre surco; la justicia es su raíz. Violeta escribe para espantar los espectros, para sanarse o soportar el mal de amores y, muy especialmente, o más bien por meterle un susto al mal con alevosía: "que la escritura da calma / a los tormentos del alma". Para ello pide ayuda a las estrellas, a su inmensa claridad, para publicar la verdad. La verdad humana que sería insoportable sin el arte -dimensión del diálogo y el encuentro con el otrocomo lo han comprobado tantos desde los mismos griegos.

También,por supuesto, le canta al amor de pareja del que poetiza frecuentes abandonos, fantasmagorías y equívocos: 
Yo soy la rosa rosada

la que murió abandonada

me olvidé de los pesares

que en otro tiempo me dio

y recibo al veleidoso

en mi camino mejor

y recibo al veleidoso

con mi cariño mejor

("Como el roble en el verano")

Asimismo está el otro amor, el de su hospitalidad, responsabilidad y generosidad a manos llenas: "Un año y ocho meses que salí al mundo a servir mi tacita de té entre las familias que beben por los ojos y por los sentidos.... En eso ando por aquí repartiendo canastas de amor, no cantando para ser aplaudida, te lo juro y créemelo (... Para mí es una alegría poder repartir mis cosas entre la gente que quiero y las que no quiero también...) (Parra, I., 2009, p. 128).

Conjunción de amor, amistad, escritura, arte y reclamo son las cartas que en su desarrollo evidencian e intensifican el carácter tierno, frágil y herido -necesitado de amor y acogida- de esta mujer que llegaría a provocar lo que unos periodistas llamaron "vampirismo político" y otros violetomanía. Es que tras su muerte, todos seríamos "violotomanos, y en la vida se la ignoró, despreció, atacó” (Dölz-Blackburn, 1991, p. 440) provocando la intensificación de la herida que traía de largo.

La grandeza es que Violeta acoge amorosamente a los vivos, pero igualmente a los muertos y a ella misma, testimoniando una y otra vez lo que Levinas llama la esencia hospitalaria del lenguaje. Ahí, en el espacio de sus poemas, cartas, tejidos, canciones, gredas, papeles, está el pueblo que falta y que en su delirio y búsqueda de una salud, la trovadora casi mítica va creando. Pueblo utópico en el que los muertos habitan, diferentes y compañeros de los vivos en múltiples intercambios (qué cierto es, querido Gilberto). Ellos no necesitan ser inmortales. No hace falta que lo sean, recuerda el autor de El intercambio simbólico y la muerte, porque esa casualidad fantástica rompería la reciprocidad (Baudrillard, 1992, p. 147). La gran poeta fabula de manera ejemplar ese pueblo que nos falta a través de su compleja, fascinante y entrañable creación. Pone su musicalidad, su habilidad manual, su competencia lingüística a ese fin. Así, su escritura trabaja con una 
retórica que fundamentalmente produce una conexión profunda y apela al otro: lector o auditor. En eso anda por aquí, con sus anáforas, paronomasias y aliteraciones; sus metonimias, encabalgamientos, apócopes, diminutivos, vocativos, cruces de reinos; con sus agenciamientos con la botánica y la zoología, la geografía humana (animización y animalización) de su patria, sus comparaciones y metáforas. Con estos rasgos retóricos y temáticos, con una superideología generosa, con múltiples discursos, compone una escritura que libera al lenguaje del anquilosamiento y de la pesadez para darle alas que lo comunican con el pueblo a través de su ternura (guarida, morada, hogar) o su rabia (amenaza, cárcel, encierro). La enunciación de objetos mínimos, de pequeñas vidas, dulces sucesos, injusticias particulares y rotundos males políticos y sociales hace que su obra se perciba como un acontecimiento de enunciación profundamente político al tiempo que íntimo y desolado. La artífice de la nueva canción chilena y gran poeta abandona toda retórica grandilocuente, todo exceso verbal y se sumerge en las voces colectivas que recuperan un exquisito y potente espacio de comunicación y presencia. Este ser de su lengua sería lo que Derrida dice que está en el otro, viene del otro, es "la venida del otro" y carga con una promesa parecida "al saludo dirigido al otro [...] al otro reconocido como mortal, finito, abandonado, privado de todo horizonte de esperanza" (Derrida, 1997, p. 109). Hablo también de la estética de lo pequeño representada en el uso de los diminutivos sustantivos y conjugaciones verbales, los nombres de personas, animales y cosas y sus devenires siempre hacia lo heterogéneo minoritario. El efecto de cercanía, coloquialidad, naturalidad, rapidez de la lengua de Violeta sugiere el predominio de la retórica de la pobreza que revela lo que descubre Heidegger en su lectura de Hölderlin: "ser-pobre es en sí el ser-rico" (Heidegger, 2006, p. 115). La poeta que tiene frío, está sola, abandonada y es apenas una voz en el mundo al revés, no carece de nada, salvo de lo necesario, puede aliviar su propio corazón, entregarse, repartir, encontrar, haciéndose cada vez más transparente, tierna, imperceptible y capaz de producir la humanidad multiplicada e ir elaborando su duelo. Violeta Parra, como Lorca o Rilke, siente la vida por vía de la muerte, pero la expresa con personalidad y acento propios, no por procesos de especulación interior, sino en torno a sí. Su reino poético está sometido a un imperio, a un poder único, mas a lo largo de su producción la poeta ha ido desahogándose de ese sofoco, de ese nudo ciego de muerte, convirtiéndose en criatura poética. 


\title{
V. "LOS PAJARILLOS NO CANTAN, NO TIENEN DONDE ANIDAR": FORMAS DE LA MUERTE EN LA POESÍA CHILENA: \\ LA FIGURACIÓN DE VIOLETA PARRA
}

\author{
Mi pecho se halla de luto \\ por la muerte del amor \\ en los jardines cultivan \\ las flores de la traición \\ oro coma el hortelano \\ que va sembrando rencor, \\ por eso llorando estoy
}

(Ibidem)

Ya sabemos que los nombres, imágenes y encuentros con la muerte son variados y múltiples en la poesía chilena: contramadre del mundo, puta caliente, acreedora, disgregadora, impura, vieja lacha, vieja cutufa, bestia tufosa, andrajosa que espía callada, bestia codiciosa de futuros espasmos, desdentada, la Señora, chaqueta amarilla, deslenguada, la mariscala, mañosa, empadronadora, avispa castrada, bicharraca asesina, descarnada, la flaca, la calva, andrógino perfecto... ¡Ay! Pero "nada tiene que ver la muerte con esta imagen de la que me retracto", avisa Enrique Lihn relativizándose la posibilidad de nombrar o describir lo innombrable (Lihn, 1989, p. 13).

Gilberto Triviños, en su estudio de 1996, evidencia un proceso que parece constitutivo de los campos poéticos de la pesadez y fuerza petrificante de la también llamada medusa. Dar forma humana a la muerte, aproximarla, ofenderla, sexualizarla, femeneizarla, son procedimientos reiterados en una poesía (re)presentada, predominantemente por varones. Entonces se le dice "cruel oledora de los recién nacidos", "vieja lacha”, "puta caliente": ¿Podría escribir esto una poeta? En cualquier caso, y disculpe la digresión, existe en la poesía chilena un reiterado tropismo antropomorfizante cuya versión final estaría en el devenir andrógino perfecto de la muerte ficcionalizada por Enrique Lihn, que seguiría con Martínez y Millán, poetas que en sus obras vacían de contenidos o forma humana a la muerte para devenir, en Millán, en espacio, imagen, autorretrato; un cuadro vacío o inerte y silencio. En Juan Luis Martínez, el libro no es sólo la tumba, sino el registro documental de la muerte de su autor. El nombre propio contiene la muerte de su portador, la muerte ya no es una "cosa", es un espacio, pero un espacio concreto: una caja que se abre y permite conocer la circunstancia imaginada ("vista y 
oída") de la muerte propia. Habría en estos poetas transgresión de la muerte y también del discurso figurativo de la muerte. Morir escribiendo, pero dejando la huella de la propia muerte que es vacío innombrable, deslexicalizado y no figurable bajo ninguna forma o estrategia.

Una línea puede ser recta, pero no el corazón del ser humano, tampoco la poesía es esa línea recta y así quiero volver a la arregladora de angelitos que escribe con la muerte y la poesía siguiéndole los pasos.

Lanceta terrible, fiera sangrienta, tiburón, avispa, animal fatigoso y altanero, escarcha animal bullicioso y pendenciero; la muerte es el fin del mundo, la muerte es el ataúd, minuto fatal, molino, insectario, cajones de muerto... Violeta Parra... la muerte es Violeta Parra... La muerte en la autora de "Y arriba quemando el sol" traspasa reinos y fronteras y toma imágenes del reino vegetal y animal, de objeto, de temporalidad. Una única vez es "la flaca"; otra, la más impresionante es la figura de una inocente, de una niña produciendo un agenciamiento que culminará en la figuración final de la muerte esta obra que no sólo es eso, son también documento y testimonio. Una obra que antes, mucho antes de Uribe Arce, Millán, Martínez sitúa en el propio rostro, pero también en la ejecución del acto, a la propia sujeto de la enunciación.

Desde "contramadre" del mundo hasta andrógino perfecto o el rostro en el espejo de la muerte, el diccionario poético de la muerte en Chile, la secuencia que sigue la ruta latinoamericana iniciada por Rubén Darío, concluye pues ilusoriamente en Lihn o Schopf o Harris, porque la poesía es encuentro y no línea sin vuelta o regreso. La nada y la sin nombre, tiene unas escenas y una forma en la poesía chilena. ¿La muerte, como deceso, acaso no es pasar una frontera, a saber, un tránsito, un extralimitarse o una transgresión (transire, "sic transit", etc.) (Derrida 1998, p. 22)? Esto es, intuyo, la gran singularidad de quien no pudo expulsar la terrible lanceta que la hizo su rehén siendo niña y que hace de su muerte un acto extremadamente complejo y con razones más profundas que las que se han señalado y que también son. Digo que en la obra de esta gran hermana, constantemente asediada por la muerte, la propia poeta es la muerte, la portadora de la lanceta es la preciosa Violeta. La generadora de la fiebre y luego del fuego, que como la lanceta quema y arde, pero también purifica, es la misma que escribe. El encuentro con la muerte ocurre temprano, desde muy pronto se la conoce y mira. Es ella misma, no es de afuera, es parte de ella, con ella canta y dispara, con ella se busca un filtro. Por ella y con ella se concibe y se consigue la obra. Hay aquí, pues, una personificación intratextual e íntima, transgresora y perfecta. El círculo se cierra y se abre la Obra. 
En esta obra que se produce más allá de los límites tradicionales de los géneros e incluye una biografía incompleta y cartas que no se han podido leer, deja liberado a nuestro propio relato y ficciones la condición profunda de la tercera secuencia. ¿Qué queda, se pregunta Gilberto Triviños, y yo con él, después del desvanecimiento del poder de la belleza (Darío) y de la risa (Nicanor) contra el terror producido después de la demolición desantropomorfizante que muestra sin velos su casa infigurable? Quedaría la nada, el vacío, el autorretrato, el locus o la verdad de Violeta que tan pronto descubre -y debe ocultar- que la muerte está en ella, que la vieja desdentada no está afuera, no es ajena, bella o fea, sino que simplemente es y camina con ella paso a paso. La verdad única que tenemos y ocultamos $\mathrm{o}$ alejamos, en una alteridad consoladora y falsa. La dulce y terrible madre que es Violeta vive con ello, y vive en la verdad o en su búsqueda. También comprende, y muy al inicio, que el amor y la obra -asimismo la amistadson las armas para vivir su propia travesía y el devenir aquello y aceptar la verdad en su tremenda plenitud. Para olvidarme de todo esto nada mejor que mi guitarra; estar separados es como estar muertos: "Te digo que estoy triste. Te digo que estoy sola. Te digo que estoy muerta. Necesito un ataúd y un discurso ridículo. Nicanor está muy lejos también. Mi mamá más lejos aún...” (Parra, I., 2009, p. 165), “A los 46 años, todavía no sé qué actitud tomar; es decir lo sé. Lo que no sé es de dónde sacar la fuerza que me haga resistir los empeñones que me propina la vida" (Parra, I., 2009, p. 140).

Niña inocente y donosita, orejón, escombra, pezuña; feliz corderito; mala madre, abandonadora; amante, amiga, hermana, abandonada, muerte. Obra y maestra mágica, los devenires de Violeta no son lineales. Tampoco su relación con ellos es siempre idéntica o molar. El personaje que vive otros múltiples devenires menores, palomita, diuquita cantora, dadora de tacitas de té, ave indefensa, frágil como un segundo, lechón, hondo raudal de espumas muy apacible, planta sin fragancia, corderillo, lobo, marcada, guitarra (pues es posible que un hombre se transforme en clarinete se nos dice), pájara ausente, chiquitita llorona, deviene en muerte; pero, fundamental e inversamente, deviene poema, canción, arpillera, greda, folklore... Vida?.

\footnotetext{
${ }^{8}$ Lucy Oporto Valencia (2007) ha escrito un vigoroso y excelente texto -que sólo conocí luego de haber terminado el presente artículo- sobre la muerte del amor en "El gavilán”, de Violeta Parra, en el cual desarrolla aspectos muy interesantes y valiosos para una continuidad en el estudio del tema de la muerte en nuestra autora. Esto ocurre fundamentalmente en la II Parte, "La muerte del amor en 'El gavilán’”. El texto pone en relación los elementos musicales, la política, la poesía, la biografía, la filosofía.
} 
La herida. Del silencio de la lanceta al sonido ominoso del disparo, desde ocultar a proclamar la verdad implacable para volver del otro lado de la noche. "La esencia de la verdad es lo que vengo diciendo... la tinta me está anunciando que todo tiene su término". ¿Y qué voy a hacer con este nudo ciego?

Violeta no vino a lucirse, quiere cantar y enseñar una verdad, quiere "cantar porque el mundo tiene pena y está más confusa que ella misma". Volver, volver, volver a los diecisiete con obra cargada de dolor, belleza, responsabilidad, verdad, justicia, arte y humor, con humor, también. Pero ¿quién es esta poeta que deviene intensidad deseante, misterio y muerte y de nuevo frágil vida? Esta poeta a la que han de utilizar tirios y troyanos y que ha permanecido indócil y única en su decir multiplicado, transparente y complejo. Tal vez, como escribe el poeta Juan Carlos Mestre (2006): “Es necesario morir para abandonar la oscura ciudadana en que todo lenguaje se convierte en expresión de algún vago/ poder/ y es necesario morir ante la importancia de algo por lo que nadie daría la vida". Tal vez Violeta no pudo como Alejandro cortar el nudo gordiano, pero indiscutiblemente permanece, así como escribe en su poema "Me voy por un senderito", también titulada "La muerte":

Me voy por un senderito sembrado de blancos yuyos y en árboles en capullo ya cantan los chincolitos. En el estero infinito se están meciendo las aguas, la sombra de la patagua me recibe con cariño, las lágrimas, del corpiño, resbalan hasta mi enagua.

Detrás de las alamedas se duermen los animales, perfuman los cereales las trémulas sementeras. Las hojas por vez postrera me brindan una sonrisa y me refresca la brisa con sus esponjas, la frente. 


\begin{abstract}
Respiro serenamente, ya nada me martiriza.

Semana que mis rosales estaban ya florecidos yo con mi malo sentido vi sólo sus espinales. Las nubes primaverales parecen una pintura, los campos con su verdura me han descorrido el telón. Mis ojos bailan al son del viento por la llanura.
\end{abstract}

Ya no me clava la estrella, ya no me amarga la luna, la vida es una fortuna vistosa, próspera y bella. Sus lluvias y sus centellas nos engalanan los aires nos brinda como una madre su aliento renovadero. Ya siento que el mundo entero está de canto y baile.

(Parra, V., 1998)

Violeta elevándose sobre la muerte, pero también con su muerte, se ha convertido en poema y yo quiero privilegiar la elegía, la vida y el canto. El tiempo y la muerte no han borrado casi nada y yo me apropio de las palabras de Foucault sobre Raymond Roussel.

El lenguaje de Violeta se opone -por el sentido de sus flechas más que por la materia con la cual está hecho- a la palabra iniciática. Este lenguaje no está construido sobre la certeza de que existe un secreto, uno solo: este lenguaje brilla con la incertidumbre radiante, puramente de superficie, que cubre una especie de vacío central: imposibilidad de decidir si hay un secreto, ninguno o varios; y cuáles son. Toda afirmación de que existe, toda definición de la obra de Violeta le impide vivir de ese vacío que moviliza, sin iluminar jamás, nuestra inquieta ignorancia... (Foucault, 1992, p. 21).

La obra de Violeta "no fabrica ser, mantiene las cosas en su ser". Su función consiste en "permanecer". Pero también en hacer "pasar", franquear los obstáculos, alborotar las cárceles y los secretos. Despertar los recuer- 
dos dormidos. Toda la creación de Violeta se abre un espacio en el cierre protector que es también el de la maravillosa comunicación. Pasaje que es clausura, umbral y llave (Foucault 1992, p. 92). Todo en esta obra -las furias y las penas, los vegetales y los animales, el grito y el sonido, el silencio, la contradicción- busca la consagración de dos funciones míticas fundamentales: unir y recuperar.

\section{REFERENCIAS}

Adorno, Theodor (1987). Minima moralia. Madrid: Taurus.

Agamben, Giorgio (2005). Lo que queda de Auschwitz. El archivo y el testigo. Valencia: Pretextos.

Agosin, Marjorie y Dölz-Blackburn, Inés (1988). Violeta Parra: Santa de pura greda. Un estudio de su obra poética. Santiago: Planeta.

Baudrillard, Jean (1992). El intercambio simbólico y la muerte. Caracas: Monteávila Latinoamérica.

Blanchot, Maurice (2004). El instante de mi muerte. La locura de la luz. Madrid: Tecnos.

Derrida, Jacques (1992). Aporías: Morir-esperarse (en) "los límites de la verdad". Buenos Aires: Paidós. (1997). El monologismo del otro. Buenos Aires: Manantial.

Dölz-Blackburn, Inés (1991). "Valorización y perfil de Violeta Parra a través de la prensa chilena, 1967-1990: una evaluación cronológica". Revista Interamericana de Bibliografía, XLI, 3, 436-478.

Echeverría, Mónica (2010). Yo, Violeta. Santiago de Chile: Plaza \& Janés.

Foucault, Michel (1992). Raymond Roussel. Buenos Aires - México D.F.: Siglo Veintiuno.

Heidegger, Martín (2006). La pobreza. Bs. As.-Madrid: Amorrortu Editores.

Kojeve, Alexandre (1983). La dialéctica de lo real y la idea de la muerte en Hegel. Buenos Aires: La Pléyade.

Lindstrom, Naomí (1995). Las décimas de Violeta Parra: Versos autobiográficos y crítica cultural, en López de Martínez, Adelaida (ed.), Discurso femenino actual: Ensayos críticos sobre la teoría del feminismo. San Juan, Puerto Rico: Editorial de la Universidad de Puerto Rico.

Lihn, Enrique (1989). Diario de muerte. Santiago de Chile: Universitaria.

Manns, Patricio (1986). Violeta Parra: la guitarra indócil. Concepción, Chile: Lar.

Mestre, Juan Carlos (2006). La tumba de Keats. Madrid: Calambur.

Millares Selena (2000). “Geografías del Edén: La poesía trovadoresca de Violeta Parra”. Anales de la Literatura Chilena No 1, 167-179.

Mulnich, Susana (1997). "El sentimiento de abandono en los textos de Violeta Parra y Gabriela Mistral”. Atenea No 475, 125-136. 
Neruda, Pablo (1982). El fin del viaje. Obra póstuma. Barcelona: Seix Barral.

Oporto Valencia, Lucy (2007). El diablo en la música. La muerte del amor en "El gavilán", de Violeta Parra. Viña del Mar, Chile: Ediciones Altazor.

Oviedo, Carmen (1990). Mentira todo lo cierto: Tras la huella de Violeta Parra. Santiago de Chile: Universitaria.

Parra, Isabel (1985). El libro mayor de Violeta Parra. Madrid: Ediciones Michay S.A.

(2009). El libro mayor de Violeta Parra. Un relato biográfico y testimonial. La Habana: Editorial José Martí.

Parra, Nicanor. 1983. Obra gruesa. Santiago: Andrés Bello.

Parra, Violeta (1970). Décimas. Autobiografía en versos chilenos. Santiago: Universidad Católica - Editorial Pomaire.

(1979). Cantos folklóricos chilenos. Santiago de Chile: Nascimento.

(1998). Décimas. Autobiografía en verso. Santiago de Chile: Editorial Sudamericana.

Ricoeur, Paul (2008). Vivo hasta la muerte. Buenos Aires: Fondo de Cultura Económica.

Subercaseaux, Bernardo y Londoño, Jaime (1976). Gracias a la vida: Violeta Parra. Testimonio. Buenos Aires: Galerna.

Subercaseaux, Bernardo; Stambuk, Patricia y Londoño, Jaime (1985). Violeta Parra. Gracias a la vida. Testimonios. Buenos Aires: Galerna.

Subirats, Eduardo (1983). El alma y la muerte. Barcelona: Anthropos.

Triviños, Gilberto (1996). "La metamorfosis de la muerte semejante a Diana en Rubén Darío, Vicente Huidobro y Nicanor Parra”. Acta Literaria No 21, 75-92.

Weil, Simone (1994). La gravedad y la gracia. Madrid: Trotta, S. A. 